\title{
CROPS AND SOILS RESEARCH PAPER Impact of depth of placement of mineral fertilizer micro-dosing on growth, yield and partial nutrient balance in pearl millet cropping system in the Sahel
}

\author{
A. IBRAHIM ${ }^{1 *}$, D. PASTERNAK ${ }^{2}$ AND D. FATONDJI ${ }^{1}$ \\ ${ }^{1}$ International Crops Research Institute for the Semi-Arid Tropics (ICRISAT), BP 12404 Niamey, Niger \\ ${ }^{2}$ International Adviser Drylands Agriculture, 16/12 Harav Goren St., Rishon Letzion 75753, Israel
}

(Received 14 January 2014; revised 1 July 2014; accepted 08 September 2014)

\section{SUMMARY}

A study was carried out in the rainy seasons of 2008 and 2009 in Niger to investigate the effects of fertilizer microdosing on root development, yield and soil nutrient exploitation of pearl millet. Different rates of diammonium phosphate (DAP) were applied to the soil at different depths and it was found that although micro-dosing with DAP increased grain yield over the unfertilized control to a similar level as broadcast DAP, doubling the micro-dosage did not increase it further. Increasing the depth of fertilizer application from 5 to $10 \mathrm{~cm}$ resulted in significant increases in root length density, and deep application of fertilizer resulted in higher yields, although the increases were generally not significant. It was postulated that the positive effect of micro-dosing resulted from better exploitation of soil nutrients because of the higher root volume. Levels of nutrients exported from the soil were at least as high in plants receiving micro-dosing as the unfertilized control, and plants receiving microdosing exported 5-10 times more phosphorus from the soil than the amount added through fertilization.

\section{INTRODUCTION}

The Sudano Sahel can be defined as the region bordered by the 300 and $800 \mathrm{~mm} /$ year rain isohyets. Pearl millet (Pennisetum glaucum L.) and grain sorghum (Sorghum bicolor L., Moench) are the major cereal crops of this region: sorghum is produced mostly on the finer textured soils whereas pearl millet is planted mostly on the coarse-textured soils.

The sandy soils of the Sudano Sahel are inherently very poor in plant nutrients, particularly in phosphorus (P) and nitrogen (N) (Bationo et al. 1998). Farmers do not apply fertilizers, mainly because of their high cost and lack of availability, but also because in the semiarid regions frequent droughts make fertilizer application a risky option (Buerkert et al. 2001). This lack of fertilizer use results in negative nutrient balances (Stoorvgel \& Smaling 1990).

The soil of the Sudano Sahel is being eroded by wind and water, resulting in massive nutrient loss

\footnotetext{
* To whom all correspondence should be addressed. Email: ibramali@myway.com
}

(Buerkert \& Hiernaux 1998). In addition most African soils, particularly the sandy soils of the Sahel, are very poor in organic matter. Marenya \& Barrett (2009) demonstrated that degraded soils with low soil organic matter content limit the marginal productivity of mineral fertilizer such that it becomes unprofitable at prevailing prices.

Spot application of fertilizers, so-called 'microdosing', was developed at the International Crops Research Institute for the Semi Arid Tropics (ICRISAT) in Niger (Tabo et al. 2007). The promoters of this technique expect that poor farmers will be ready to purchase small amounts of fertilizers $(0 \cdot 20$ 0.30 of the recommended rate) if they will receive the same yield as with the higher amount. MuehligVersen et al. (2003) demonstrated that micro-dosing of $\mathrm{P}$ fertilizers on pearl millet in an acid, sandy soil at a rate of $3-5 \mathrm{~kg} / \mathrm{ha}$ gave almost the same grain yield and total dry matter as broadcasting $\mathrm{P}$ fertilizer at a rate of $15-20 \mathrm{~kg} / \mathrm{ha}$, which is the recommended rate in the Sahel (Bationo \& Mokwunye 1991). Fertilizer micro-dosing has been adopted by the 
Alliance for a Green Revolution in Africa (AGRA) as a major innovation to benefit 360000 farmers in the Sahelian region of Africa (Bationo \& Waswa 2011).

However, very few, if any, attempts have been made to explain why a small amount of fertilizer given as a micro-dose results in dry matter and grain yield similar to that obtained by the recommended rate of fertilizer applied through broadcasting. The hypothesis that more of those fertilizers spread over the whole field are lost through leaching without reaching the roots than those applied near the plant is only partially true. Millet roots are well spread (horizontally and vertically) over the field (Hafner et al. 1993) and should therefore be able to capture broadcast fertilizers. In pearl millet fertilizers, particularly phosphorus, result in marked increases in root biomass production (Bagayoko et al. 2000a). Spot application of manure combined with nitrogen-phosphorus-potassium (NPK) fertilizer also significantly increased root development of watermelon under rain-fed conditions in the Sahel (Fatondji et al. 2008).

It is therefore reasonable to suggest that a major effect of fertilizer micro-dosing is induction of root proliferation. This, in turn, should result in better exploration of the soil for nutrients, thus explaining the remarkable benefits of micro-dosing. If the benefit of fertilizer micro-dosing is manifested through root proliferation then deep placement of fertilizer should result in higher root development in deeper soil layers and hence in better nutrient exploitation.

Another aspect that is not discussed by the promoters of fertilizer micro-dosing is the fact that the relatively large amount of dry matter that is produced through fertilizer micro-dosing may remove more nutrients from the soil than the amount supplied through fertilizer micro-dosing. In other words, fertilizer micro-dosing could result in nutrient depletion of the soil and eventually in soil impoverishment.

The present study was therefore conducted to: (i) evaluate the effect of mineral fertilizer micro-dosing on root growth; (ii) evaluate the effect of deep placement of fertilizer micro-dose on millet yield and (iii) assess the partial nutrient balance under fertilizer micro-dose technology.

\section{MATERIALS AND METHODS}

\section{Experimental site}

The experiment was conducted at the Sadoré research station of the International Crops Research Institute for the Semi-Arid Tropics (ICRISAT) in Niger $\left(13^{\circ} 15^{\prime} \mathrm{N}\right.$ and $2^{\circ} 18^{\prime} \mathrm{E}, 240 \mathrm{~m}$ a.s.l.). The climate is characterized by a rainy season that occurs between June and September, and a dry season that prevails during the rest of the year. The mean annual rainfall at Sadoré is $560 \mathrm{~mm}$ (Sivakumar \& Salaam 1999) and average temperature is $29^{\circ} \mathrm{C}$ (West et al. 1984). The soil is classified as a sandy siliceous isohyperthemic Psammentic Paleustalf in the USDA Soil Taxonomy (Soil Survey Staff 1999). It belongs to the Labucheri type, characterized by a high sand content, low native fertility with low organic matter and low cation exchange capacity that limits nutrient storage and water holding capacity. These soils are generally very strongly to strongly acidic $(\mathrm{pH} 4 \cdot 5-5 \cdot 0)$, with aluminium comprising a high proportion $(0 \cdot 47)$ of the exchangeable cations (West et al. 1984). Soil water content at field capacity is $0 \cdot 09-0 \cdot 10 \mathrm{~m}^{3} / \mathrm{m}^{3}$ (Klaij \& Vachaud 1992).

\section{Experimental design}

The trial was conducted in the 2008 and 2009 rainy seasons. The experimental fields had been left fallow for 7 years; soil chemical characteristics of the two fields are presented in Table 1. The micro-dosing treatments used in 2008 were 20 and $40 \mathrm{~kg} / \mathrm{ha}$ of diammonium phosphate (DAP), corresponding to 2 and $4 \mathrm{~g}$ DAP, applied at a depth of 5 and $10 \mathrm{~cm}$ in each planting hole, termed a pocket (each pocket occupied $1 \mathrm{~m}^{2}$ ), and a control treatment without fertilizer. In 2009, an additional treatment was added: $200 \mathrm{~kg}$ DAP/ha broadcast over the plots. The application of $20 \mathrm{~kg}$ DAP/ha contains $4 \mathrm{~kg}$ P/ha and $3.6 \mathrm{~kg} \mathrm{~N} / \mathrm{ha}$ as ammonium. The experiments were arranged in a randomized complete block design with five replications. Individual $7 \times$ $7 \mathrm{~m}$ plots were separated by a $1.5 \mathrm{~m}$ alley.

Pearl millet seeds (local variety Sadoré) were sown on 19 June 2008 and 13 June 2009 in pockets dug with a hand hoe spaced at $1 \times 1 \mathrm{~m}$, giving a density of 10000 pockets/ha. Millet seedlings were thinned to two plants per pocket 3 weeks after planting and plots were weeded twice in each experimental year with a long-handled hoe known as a hilaire.

\section{Data collection and analysis}

Rainfall data were recorded by means of a rain gauge located at the experimental site. Soil samples were taken from each plot in 2008 and 2009 at the onset of the experiment at depths of 0-10, 10-20 and 20- 
Table 1. Chemical properties of the soil before planting

\begin{tabular}{|c|c|c|c|c|c|c|c|c|}
\hline & \multicolumn{4}{|c|}{2008} & \multicolumn{4}{|c|}{2009} \\
\hline & $\begin{array}{l}\mathrm{pH}-\mathrm{H}_{2} \mathrm{O} \\
(1: 2 \cdot 5)\end{array}$ & $\mathrm{OC}(\mathrm{g} / \mathrm{kg})$ & $\begin{array}{l}\text { Total-N } \\
(\mathrm{mg} / \mathrm{kg})\end{array}$ & $\begin{array}{l}\text { P available } \\
(\mathrm{mg} / \mathrm{kg})\end{array}$ & $\begin{array}{l}\mathrm{pH}-\mathrm{H}_{2} \mathrm{O} \\
(1: 2 \cdot 5)\end{array}$ & OC $(\%)$ & $\begin{array}{l}\text { Total-N } \\
(\mathrm{mg} / \mathrm{kg})\end{array}$ & $\begin{array}{l}\text { P available } \\
(\mathrm{mg} / \mathrm{kg})\end{array}$ \\
\hline \multicolumn{9}{|c|}{ Depth (cm) } \\
\hline 10 & $\begin{array}{l}5 \cdot 0 \\
(0 \cdot 04)\end{array}$ & $\begin{array}{l}1 \cdot 8 \\
(0 \cdot 02)\end{array}$ & $\begin{array}{l}182 \\
(21 \cdot 6)\end{array}$ & $\begin{array}{l}17 \\
(3 \cdot 2)\end{array}$ & $\begin{array}{l}5 \cdot 0 \\
(0 \cdot 12)\end{array}$ & $\begin{array}{l}2 \cdot 3 \\
(0 \cdot 03)\end{array}$ & $\begin{array}{l}207 \\
(23 \cdot 2)\end{array}$ & $\begin{array}{l}26 \\
(2 \cdot 2)\end{array}$ \\
\hline 20 & $\begin{array}{l}5 \cdot 3 \\
(0 \cdot 01)\end{array}$ & $\begin{array}{l}1 \cdot 2 \\
(0 \cdot 02)\end{array}$ & $\begin{array}{l}119 \\
(16 \cdot 2)\end{array}$ & $\begin{array}{l}11 \\
(1 \cdot 4)\end{array}$ & $\begin{array}{l}5 \cdot 1 \\
(0 \cdot 04)\end{array}$ & $\begin{array}{l}1 \cdot 4 \\
(0 \cdot 01)\end{array}$ & $\begin{array}{l}130 \\
(9 \cdot 4)\end{array}$ & $\begin{array}{l}14 \\
(3 \cdot 9)\end{array}$ \\
\hline 40 & $\begin{array}{l}5 \cdot 2 \\
(0 \cdot 03)\end{array}$ & $\begin{array}{l}0 \cdot 8 \\
(0 \cdot 01)\end{array}$ & $\begin{array}{l}96 \\
(8 \cdot 2)\end{array}$ & $\begin{array}{l}3 \cdot 3 \\
(0 \cdot 36)\end{array}$ & $\begin{array}{l}5 \cdot 1 \\
(0 \cdot 07)\end{array}$ & $\begin{array}{l}1 \cdot 0 \\
(0 \cdot 00)\end{array}$ & $\begin{array}{l}92 \\
(7 \cdot 3)\end{array}$ & $\begin{array}{l}4 \\
(1 \cdot 8)\end{array}$ \\
\hline 60 & $\begin{array}{l}5 \cdot 1 \\
(0 \cdot 05)\end{array}$ & $\begin{array}{l}0 \cdot 8 \\
(0 \cdot 01)\end{array}$ & $\begin{array}{l}102 \\
(8 \cdot 8)\end{array}$ & $\begin{array}{l}3 \cdot 5 \\
(0 \cdot 27)\end{array}$ & $\begin{array}{l}5 \cdot 0 \\
(0 \cdot 07)\end{array}$ & $\begin{array}{l}0 \cdot 7 \\
(0 \cdot 01)\end{array}$ & $\begin{array}{l}84 \\
(7 \cdot 4)\end{array}$ & $\begin{array}{l}2 \cdot 1 \\
(0 \cdot 18)\end{array}$ \\
\hline
\end{tabular}

$\mathrm{H}_{2} \mathrm{O}$, water; $\mathrm{OC}$, organic carbon; $\mathrm{N}$, nitrogen; $\mathrm{P}$, phosphorus.

Numbers in brackets indicate standard error.

$40 \mathrm{~m}$. Each sample was analysed for $\mathrm{pH}$ (measured using distilled water) (ammonium acetate $\left(\mathrm{NH}_{4} \mathrm{AcO}\right)$ at $\mathrm{pH} 7$; soil/water ratio of $1: 2 \cdot 5)$, organic carbon (Walkley \& Black 1934) and total $N$ using the Kjeldhal method (Houba et al. 1995). Available phosphorus was determined with the Bray 1 method using extraction with a combination of $0 \cdot 025 \mathrm{~N}$ hydrochloric acid $(\mathrm{HCl})$ and $0.03 \mathrm{~N}$ ammonium fluoride $\left(\mathrm{NH}_{4} \mathrm{~F}\right)$, and the colorimetric method of the phosphomolybdate complex, reduced with ascorbic acid (Houba et al. 1995).

Root samples were collected on each plant sampling date $(26,65$ and 87 days after sowing (DAS) in 2008 and 38, 65 and 87 days after planting in 2009) with a metal frame measuring $20 \times 20 \times 10 \mathrm{~cm}$ from 0 to $20 \mathrm{~cm}$. Below this depth, root samples were collected at $20 \mathrm{~cm}$ increments with an aluminium tube of $7.5 \mathrm{~cm}$ internal diameter. The sampling depth was measured from the soil surface. The roots were washed and root length was determined by the grid counting method (Newman 1966). A grid size of $2 \times 2 \mathrm{~cm}$ was used for coarse roots and $1 \times 1 \mathrm{~cm}$ for fine roots. The coarse roots were counted on a sub-sample of $2 \mathrm{~g}$ taken from the main sample. In the case of the fine roots, if the fresh weight of the total sample was $>1 \mathrm{~g}$, a sub-sample of $1 \mathrm{~g}$ was taken for the count. The samples were cut into small pieces of $1 \mathrm{~cm}$ and spread in a dish with a small amount of water. Roots were weighed after oven-drying at $65{ }^{\circ} \mathrm{C}$ for $48 \mathrm{~h}$. Root length $(\mathrm{R})$ was calculated using the following formula (Tennant 1975):

$R=(N \times$ total root fresh weight $) /$ Root sub - sample where $N$ is number of intersections counted. Root length density (RLD) was determined using $R L D=$ $R / V$, where $R$ is root length and $V$ is soil volume of corresponding depth.

Harvest dates were 20 October 2008 and 14 October 2009 and the harvested area was $5 \times 5 \mathrm{~m}$. The number of tillers $/ \mathrm{m}^{2}$ and number of heads $/ \mathrm{m}^{2}$ were counted for the plants in 12 planting holes (pockets) randomly selected in each treatment and averaged to obtain the number of tillers or heads $/ \mathrm{m}^{2}$. Thousand grain weight was measured using an electronic balance with an accuracy of 0.001 g. To determine grain yield and dry matter yield, samples of straw and manually threshed millet panicles collected from the harvested area $\left(25 \mathrm{~m}^{2}\right)$ were oven-dried at $65{ }^{\circ} \mathrm{C}$ for $48 \mathrm{~h}$, weighed and expressed in $\mathrm{kg} / \mathrm{ha}$. In order to determine nutrient uptake by the millet, whole plants were sampled from five pockets in each treatment. The samples were separated into leaves, stems, glumes and grains and oven-dried at $65{ }^{\circ} \mathrm{C}$ for $48 \mathrm{~h}$. Sub-samples of the dried plant material were milled for total N, P and K analysis. Samples were digested with sulphuric acid $\left(\mathrm{H}_{2} \mathrm{SO}_{4}\right)+$ salicylic acid+ hydrogen peroxide $\left(\mathrm{H}_{2} \mathrm{O}_{2}\right)+$ selenium. The quantitative determination for total $\mathrm{N}$ was carried out using an auto-Analyser (Pulse Instrumentation Ltd, Saskatoon, Saskatchewan, Canada) using the colorimetric method based on the Bertholet reaction (Houba et al. 1995). Total $P$ was determined with the colorimetric method based on the phosphomolybdate complex, reduced with ascorbic acid (Houba et al. 1995) and total $\mathrm{K}$ was determined with flame emission spectrophotometry. A partial nutrient balance was calculated 

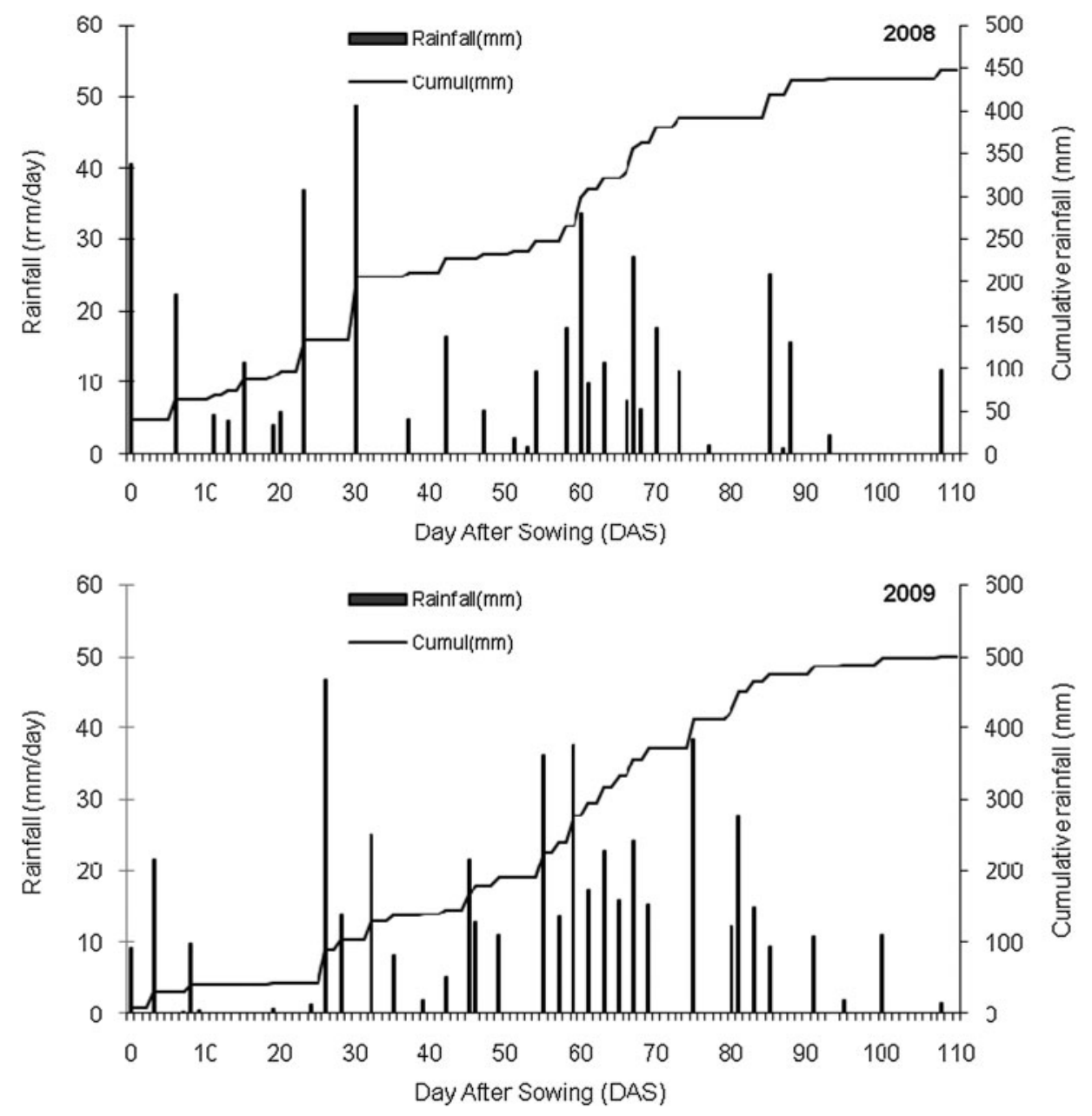

Fig. 1. Accumulation and distribution of rainfall during the experimental period in 2008 and 2009.

by subtracting the amount of $\mathrm{N}, \mathrm{P}$ or $\mathrm{K}$ taken up by the (grain, glumes and straws) from the total amount of $\mathrm{N}$, $\mathrm{P}$ or $\mathrm{K}$ added through fertilizer.

Statistical analysis

Data collected were subjected to analysis of variance within each year using GENSTAT v. 9 (Lawes Agricultural Trust 2007). Means were compared between treatments by least significant difference (LSD) at $P<0 \cdot 05$.

\section{RESULTS}

\section{Rainfall distribution}

Rainfall and cumulative rainfall during the two experimental years are given in Fig. 1. Total rainfall was $450 \mathrm{~mm}$ in 2008 and $500 \mathrm{~mm}$ in 2009. Rainfall distribution during the growing season was fairly even in 2008 except for a long dry spell towards the end of the season. Rainfall distribution in 2009 was also satisfactory except for a dry spell at the beginning of the growing season.

\section{Characteristics of experimental field}

Soil fertility parameters prior to sowing in the two experimental years are presented in Table 1. Soil organic carbon in the two experimental fields was very low, ranging from $2 \mathrm{~g} / \mathrm{kg}$ at the $10 \mathrm{~cm}$ soil layer down to about $0 \cdot 8 \mathrm{~g} / \mathrm{kg}$ at the 40 and $60 \mathrm{~cm}$ layers. Soil pH was about 5 at all depths in both experimental fields. The 2009 field had a higher initial concentration of $\mathrm{P}$ and $\mathrm{N}$ as compared with the 2008 field.

Effect of treatments on millet grain yield and yield components

The effect of experimental treatments on grain yield and total dry matter of pearl millet in 2008 and 2009 
Table 2. Effect of treatments on pearl millet grain yield and total dry matter in two consecutive years

\begin{tabular}{|c|c|c|c|c|}
\hline \multirow[b]{2}{*}{ Treatments } & \multicolumn{2}{|c|}{2008} & \multicolumn{2}{|c|}{2009} \\
\hline & Grain yield (kg/ha) & Total dry matter (kg/ha) & Grain yield (kg/ha) & Total dry matter $(\mathrm{kg} / \mathrm{ha})$ \\
\hline Control & $508 \pm 78$ & $2126 \pm 263$ & $562 \pm 38$ & $2094 \pm 87$ \\
\hline DAP (20 kg/ha) at10 cm & $1097 \pm 101$ & $3501 \pm 225$ & $1336 \pm 127$ & $3876 \pm 254$ \\
\hline DAP (20 kg/ha) at $5 \mathrm{~cm}$ & $918 \pm 76$ & $3231 \pm 192$ & $1091 \pm 170$ & $3488 \pm 211$ \\
\hline DAP $(40 \mathrm{~kg} / \mathrm{ha})$ at $10 \mathrm{~cm}$ & $1053 \pm 155$ & $3475 \pm 296$ & $1225 \pm 131$ & $3667 \pm 199$ \\
\hline DAP (40 kg/ha) at $5 \mathrm{~cm}$ & $909 \pm 85$ & $3298 \pm 264$ & $1008 \pm 68$ & $3281 \pm 213$ \\
\hline DAP $(200$ kg/ha $)$ & - & & $1127 \pm 212$ & $3669 \pm 132$ \\
\hline$P$ & $<0 \cdot 001$ & $<0 \cdot 01$ & $<0 \cdot 001$ & $<0 \cdot 001$ \\
\hline LSD $(0 \cdot 05)$ & 225 & 776 & 318 & 736 \\
\hline CV $(\%)$ & $19 \cdot 5$ & $18 \cdot 4$ & $23 \cdot 2$ & $16 \cdot 7$ \\
\hline
\end{tabular}

Table 3. Effect of micro-dosing placement and of fertilizer amount on yield parameters in pearl millet

\begin{tabular}{|c|c|c|c|c|c|c|}
\hline \multirow[b]{2}{*}{ Treatments } & \multicolumn{3}{|c|}{2008} & \multicolumn{3}{|c|}{2009} \\
\hline & $\begin{array}{l}\text { No. } \\
\text { tillers } / \mathrm{m}^{2}\end{array}$ & $\begin{array}{l}\text { No. } \\
\text { heads } / \mathrm{m}^{2}\end{array}$ & $\begin{array}{l}1000 \text { grain } \\
\text { weight }(\mathrm{g})\end{array}$ & $\begin{array}{l}\text { No. } \\
\text { tillers } / \mathrm{m}^{2}\end{array}$ & $\begin{array}{l}\text { No. } \\
\text { heads } / \mathrm{m}^{2}\end{array}$ & $\begin{array}{l}1000 \text { grain } \\
\text { weight (g) }\end{array}$ \\
\hline Control & $4 \cdot 0 \pm 0 \cdot 41$ & $2 \cdot 3 \pm 0 \cdot 15$ & $8 \cdot 5 \pm 0 \cdot 25$ & $6 \cdot 4 \pm 0 \cdot 28$ & $3 \cdot 3 \pm 0 \cdot 12$ & $8 \cdot 7 \pm 0 \cdot 35$ \\
\hline DAP $(20 \mathrm{~kg} / \mathrm{ha})$ at10 cm & $6 \cdot 4 \pm 0 \cdot 38$ & $3 \cdot 4 \pm 0 \cdot 17$ & $10 \cdot 8 \pm 0 \cdot 33$ & $9 \cdot 0 \pm 0 \cdot 35$ & $5 \cdot 1 \pm 0 \cdot 39$ & $11 \cdot 7 \pm 0 \cdot 15$ \\
\hline DAP (20 kg/ha) at $5 \mathrm{~cm}$ & $6 \cdot 1 \pm 0 \cdot 49$ & $3 \cdot 2 \pm 0 \cdot 14$ & $9 \cdot 5 \pm 0 \cdot 13$ & $8 \cdot 6 \pm 0 \cdot 36$ & $4 \cdot 1 \pm 0 \cdot 59$ & $10 \cdot 6 \pm 0 \cdot 40$ \\
\hline DAP $(40 \mathrm{~kg} / \mathrm{ha})$ at $10 \mathrm{~cm}$ & $5 \cdot 6 \pm 0 \cdot 30$ & $3 \cdot 3 \pm 0 \cdot 28$ & $9 \cdot 7 \pm 0 \cdot 21$ & $8 \cdot 7 \pm 0 \cdot 30$ & $4 \cdot 3 \pm 0 \cdot 32$ & $10 \cdot 4 \pm 0 \cdot 38$ \\
\hline DAP (40 kg/ha) at $5 \mathrm{~cm}$ & $5 \cdot 7 \pm 0 \cdot 49$ & $3 \cdot 0 \pm 0 \cdot 26$ & $9 \cdot 3 \pm 0 \cdot 27$ & $7 \cdot 5 \pm 0 \cdot 58$ & $3 \cdot 8 \pm 0 \cdot 15$ & $9 \cdot 7 \pm 0 \cdot 35$ \\
\hline DAP (200 kg/ha) & - & - & - & $8 \cdot 4 \pm 0 \cdot 54$ & $3 \cdot 9 \pm 0 \cdot 13$ & $9 \cdot 2 \pm 0 \cdot 34$ \\
\hline$P$ & $<0 \cdot 05$ & $<0 \cdot 001$ & $<0 \cdot 01$ & $<0 \cdot 01$ & $<0 \cdot 05$ & $<0 \cdot 001$ \\
\hline LSD $(0 \cdot 05)$ & $1 \cdot 3$ & $0 \cdot 4$ & $1 \cdot 0$ & $1 \cdot 4$ & $1 \cdot 1$ & $1 \cdot 1$ \\
\hline CV $(\%)$ & $17 \cdot 8$ & $12 \cdot 2$ & $14 \cdot 8$ & $12 \cdot 6$ & $19 \cdot 7$ & $8 \cdot 5$ \\
\hline
\end{tabular}

is presented in Table 2. The grain yields were higher in 2009 compared with 2008 but there was no significant difference in grain yield between the two fertilizer application depths $(5$ and $10 \mathrm{~cm}$ ) in the 2 years. However, grain yield of pearl millet with deeper fertilizer placing tended to be higher than in the shallower placing in all instances, with one case in 2009 being significantly higher $(1336$ v. $1008 \mathrm{~kg} / \mathrm{ha})$. In both years fertilizer micro-dosing doubled the grain yield of pearl millet as compared with the non-fertilized control. In 2009, broadcasting of $200 \mathrm{~kg}$ DAP/ha did not increase grain yield when compared with micro-dosing. Doubling fertilizer rate had no effect on grain yield. Fertilizer application increased total dry matter production of pearl millet as compared with the unfertilized control but there were no differences in dry matter yield as a result of depth of fertilizer application or of amount of fertilizer. The effects of micro-dosing placement and fertilizer amount on three determinants of grain yield are presented in Table 3. In 2009, fertilizer micro-dosing increased the number of tillers, the number of heads $/ \mathrm{m}^{2}$ and the grain weight of millet as compared with the non-fertilized control. In the same year, fertilizer micro-dosing with $20 \mathrm{~kg}$ DAP/ha at $10 \mathrm{~cm}$ resulted in higher numbers of tillers $(6 \cdot 4 \quad v .5 \cdot 7)$ and of heads $/ \mathrm{m}^{2}(5 \cdot 1$ v. $3 \cdot 8)$ than fertilizer micro-dosing of $40 \mathrm{~kg}$ DAP/ha at $5 \mathrm{~cm}$.

Effect of treatment on root length density

There were no significant differences in RLD between the 20 and $40 \mathrm{~kg} / \mathrm{ha}$ fertilizer treatments. Although some pearl millet roots could be found at a depth of $200 \mathrm{~cm}$, most of the roots were concentrated in the upper $40 \mathrm{~cm}$ of the soil profile at all times (Figs 2 and 3). The RLD increased significantly $(P<0 \cdot 05)$ with millet development in all treatments. At all 

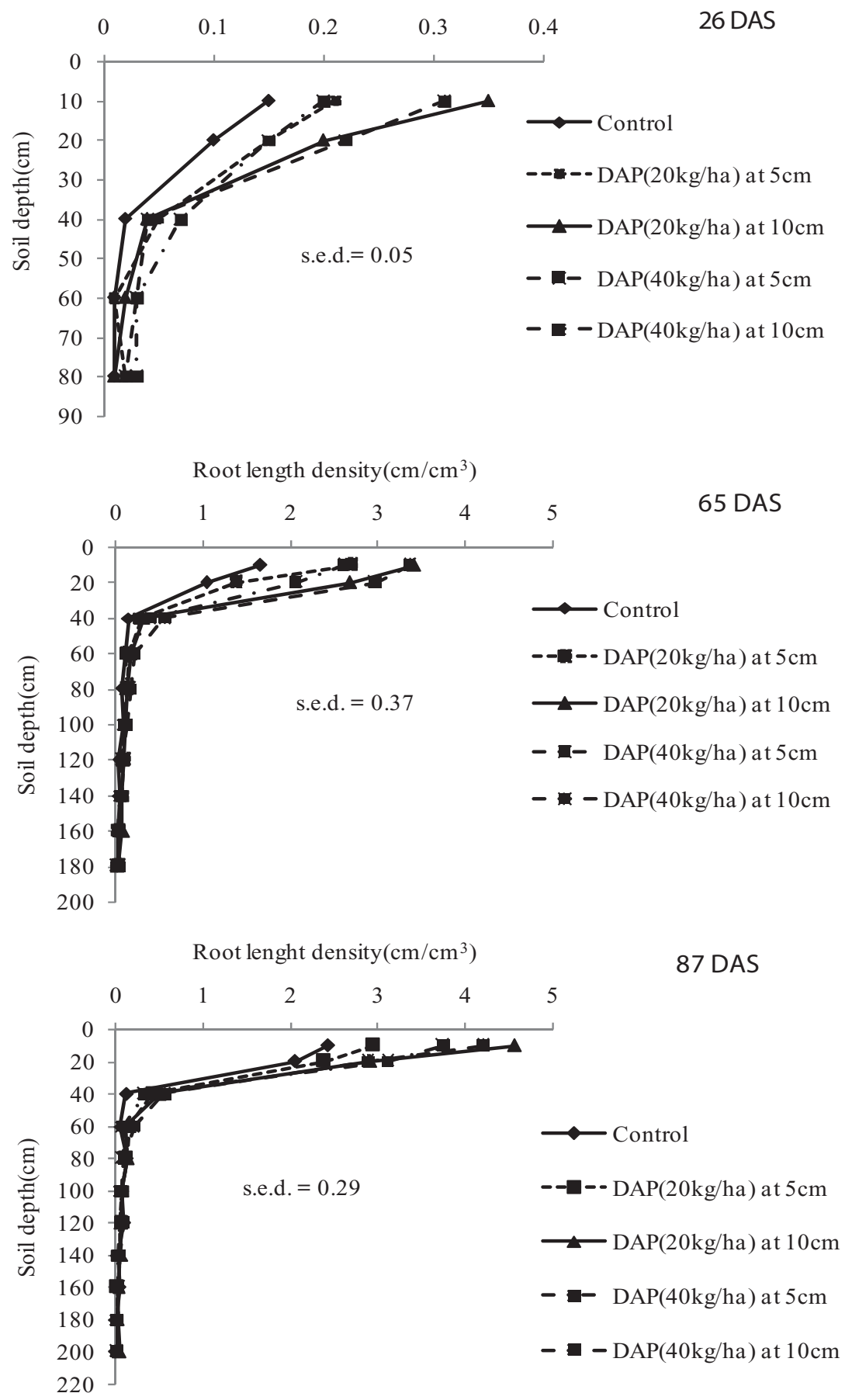

Fig. 2. RLD of pearl millet at 26,67 and 87 DAS in 2008 rainy season. DAP, diammonium phosphate.

sample dates, RLD of the fertilizer micro-dosing treatments and of the broadcast fertilizer were significantly $(P<0 \cdot 05)$ higher than that of the non-fertilized control. During the early stages of millet growth (26 and 38 days after planting), RLD in the $10 \mathrm{~cm}$-deep treatment was c. $50 \%$ greater than the RLD in the $5 \mathrm{~cm}$-deep treatment. The differences between these two treatments diminished with time. In 2009, RLD of plants receiving $200 \mathrm{~kg} / \mathrm{ha}$ DAP broadcasted was similar to that of the plants receiving fertilizer micro-dosing. 

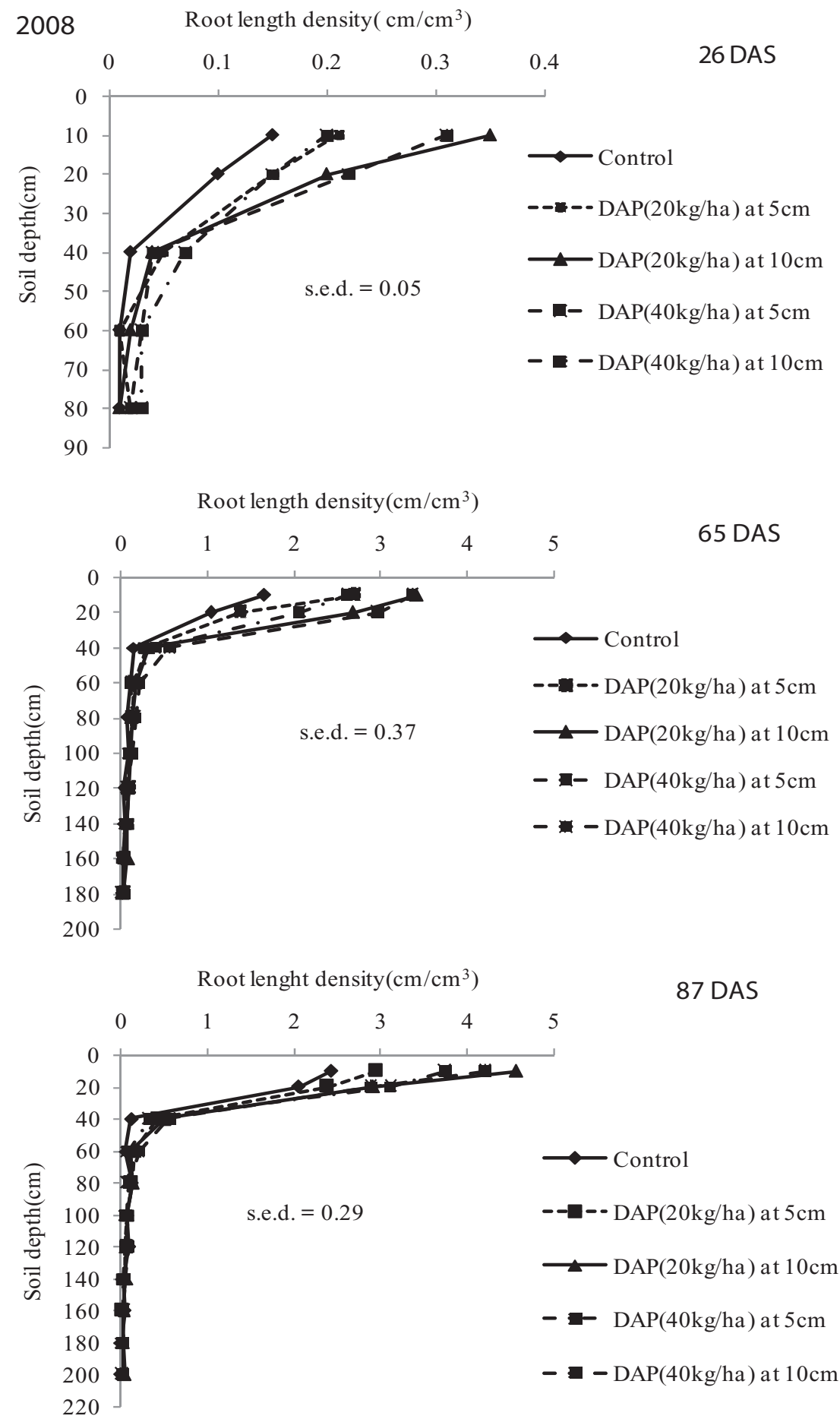

Fig. 3. RLD of pearl millet at 38,67 and 87 DAS in 2009 rainy season. DAP, diammonium phosphate.

Effect of treatments on nutrient uptake

Table 4 gives the partial balance of $\mathrm{N}, \mathrm{P}$ and $\mathrm{K}$ when micro-dosing and fertilizer broadcasting were applied. These values were achieved by subtracting the amount of nutrients in the pearl millet (grain, glumes and straws) from the amount of nutrients
( $\mathrm{N}$ and $\mathrm{P}$ ) given to the field in the form of DAP. In 2009, less $\mathrm{K}$ and more $\mathrm{P}$ and $\mathrm{N}$ were extracted from the soil as compared with 2008. In 2009 the amount of $\mathrm{P}$ extracted by the control plants that did not receive fertilizer was $19 \mathrm{~kg} / \mathrm{ha}$. The average amount of $\mathrm{P}$ extracted from the soil in the four micro-dosing 
Table 4. Effect of fertilizer micro-dosing on $N, P$ and $K$ partial nutrients balance ( \pm standard error)

\begin{tabular}{|c|c|c|c|c|c|c|}
\hline \multirow[b]{2}{*}{ Treatments } & \multicolumn{3}{|c|}{2008} & \multicolumn{3}{|c|}{2009} \\
\hline & $\mathrm{N}$ & $\mathrm{P}$ & K & $\mathrm{N}$ & $\mathrm{P}$ & $\mathrm{K}$ \\
\hline Control & $-8 \pm 1 \cdot 0$ & $-2 \pm 0 \cdot 3$ & $-12 \pm 3 \cdot 4$ & $-35 \pm 2 \cdot 3$ & $-11 \pm 0 \cdot 8$ & $-75 \pm 2 \cdot 2$ \\
\hline DAP $(20 \mathrm{~kg} / \mathrm{ha})$ at10 $\mathrm{cm}$ & $-15 \pm 1 \cdot 8$ & $-1 \pm 0 \cdot 1$ & $-25 \pm 6 \cdot 3$ & $-65 \pm 7 \cdot 4$ & $-17 \pm 1 \cdot 4$ & $-115 \pm 9 \cdot 3$ \\
\hline DAP (20 kg/ha) at $5 \mathrm{~cm}$ & $-13 \pm 3 \cdot 4$ & $-2 \pm 0 \cdot 8$ & $-21 \pm 2 \cdot 3$ & $-56 \pm 9 \cdot 3$ & $-14 \pm 2 \cdot 3$ & $-105 \pm 8 \cdot 7$ \\
\hline DAP $(40 \mathrm{~kg} / \mathrm{ha})$ at $10 \mathrm{~cm}$ & $-13 \pm 2 \cdot 3$ & $3 \pm 0 \cdot 4$ & $-24 \pm 4 \cdot 1$ & $-64 \pm 8 \cdot 4$ & $-11 \pm 4 \cdot 2$ & $-115 \pm 11 \cdot 3$ \\
\hline DAP (40 kg/ha) at $5 \mathrm{~cm}$ & $-11 \pm 3 \cdot 3$ & $3 \pm 0.9$ & $-22 \pm 3 \cdot 2$ & $-42 \pm 2 \cdot 4$ & $-9 \pm 1 \cdot 9$ & $-95 \pm 9 \cdot 4$ \\
\hline DAP $(200 \mathrm{~kg} / \mathrm{ha})$ & - & - & - & $-16 \pm 4 \cdot 2$ & $24 \pm 2 \cdot 4$ & $-114 \pm 8 \cdot 4$ \\
\hline$P$ & NS & $<0 \cdot 001$ & $<0 \cdot 05$ & $<0 \cdot 001$ & $<0 \cdot 001$ & $<0.05$ \\
\hline LSD $(0 \cdot 05)$ & $7 \cdot 0$ & $2 \cdot 3$ & $7 \cdot 3$ & $19 \cdot 8$ & $6 \cdot 2$ & $24 \cdot 6$ \\
\hline $\mathrm{CV}(\%)$ & 19 & $27 \cdot 6$ & $26 \cdot 4$ & $32 \cdot 4$ & $34 \cdot 2$ & $18 \cdot 1$ \\
\hline
\end{tabular}

NS, not significant.

treatments was $27.5 \mathrm{~kg} / \mathrm{ha}$, i.e. $45 \%$ more than in the control. Similarly, the micro-dosed plants extracted $65 \%$ more $\mathrm{N}$ from the soil compared with the non-fertilized control. In 2008 the situation was similar but less striking than in 2009. In the plots receiving 200 $\mathrm{kg}$ DAP/ha via broadcasting, more phosphorus was left in the soil than was taken by the plants.

\section{DISCUSSION}

The present study was undertaken to evaluate the effect of placement of fertilizer micro-dosing on root development and on yield of pearl millet and to assess the partial nutrient balance under fertilizer micro-dosing technology. The results showed that micro-dosing with DAP results in significant growth and proliferation of pearl millet roots, especially when fertilizer was placed at a depth of $10 \mathrm{~cm}$ compared with the common placement depth of $5 \mathrm{~cm}$. Proliferation of pearl millet roots under fertilizer micro-dosing can be explained by the low level of $\mathrm{P}$ in the soil. Bagayoko et al. (2000b) demonstrated that application of $\mathrm{P}$ to severely $\mathrm{P}$-deficient soils in West Africa resulted in large increases in early root growth, a pre-requisite for early mycorrhizal infection and later for the significant contribution of vesicular arbuscular mycorrhizae to enhanced plant growth and nutrient uptake. This is probably what has happened in the present study. The increase in root growth observed in the present study with deep placement of mineral fertilizer was in line with the findings reported by Fatondji et al. (2008), who showed that the deep placement of soil amendments markedly increased watermelon root development in deeper soil layers.
Fertilizer micro-dosing with DAP $\left(2 \mathrm{~g} / \mathrm{m}^{2}\right)$ at $10 \mathrm{~cm}$ resulted in higher numbers of tillers and of heads $/ \mathrm{m}^{2}$ than fertilizer micro-dosing applied at $5 \mathrm{~cm}$. This could explain the higher grain yield obtained for the $10 \mathrm{~cm}$-deep treatment. Grain yields recorded in 2009 were higher than those obtained in 2008, which could be attributed to the relatively higher levels of available $\mathrm{P}$ and total $\mathrm{N}$ in the soil, as well as to higher rainfall and better rainfall distribution in 2009. These findings confirm the results of earlier works that show the importance of soil fertility and water availability for enhancing crop production in Sahelian zones (Bationo \& Mokwunye 1991; Bationo et al. 1993). In 2009 broadcasting of $200 \mathrm{~kg}$ $\mathrm{DAP} / \mathrm{ha}$ did not increase grain yield compared with micro-dosing. This reinforces the case for fertilizer micro-dosing as a means to save fertilizer for grain millet production (Bagayoko et al. 2000b, 2011; Buerkert et al. 2001; Tabo et al. 2007; Aune \& Bationo 2008; Twomlow et al. 2011). The application of $20 \mathrm{~kg} \mathrm{DAP} / \mathrm{ha}$ in the form of micro-dosing can double the grain yield compared with zero application of fertilizer; however, doubling this rate (from 20 to 40 $\mathrm{kg} / \mathrm{ha}$ ) had no effect on grain yield. Perhaps there were limiting factors (Von Liebig 1940) that prevented expression of the additional fertilizer in terms of yield increase: for example, in the present study, the low level of soil organic carbon could be a major limiting factor restricting millet response to doubling the level of mineral fertilizer. Zingore et al. (2008) showed that application of $\mathrm{N}$ fertilizer in a soil rich in organic matter increased grain yields of maize significantly; however, application of $\mathrm{N}$ fertilizer in a soil poor in organic matter did not have any effect on grain yield. Marenya \& Barrett (2009) also 
demonstrated that soil organic carbon can become a 'limiting factor' for mineral fertilizer application. Bationo et al. (1998) showed that fertilizer application to a field receiving manure for 30 years resulted in a $2500 \mathrm{~kg} / \mathrm{ha}$ millet grain yield. If the same amount of fertilizer was applied to a field that did not receive manure, grain yield was only $900 \mathrm{~kg} / \mathrm{ha}$. The results obtained in the present study showed that increasing application of DAP above $20 \mathrm{~kg} / \mathrm{ha}$ will not apparently be effective without an increase in the organic matter content in the soil.

The high quantity of nutrients taken up by grain, glumes and straw in the various fertilizer microdosing treatments shows that the amount of nutrients applied through micro-dosing fertilizer was not sufficient to meet crop needs for biomass production.

Stoorvogel \& Smaling (1990) demonstrated that farmers in the Sahel are severely depleting the nutrients stored in the soil because they are not adding fertilizers (the so-called 'soil mining' activity). This leads to land degradation. Table 4 shows that nutrient depletion by plants receiving micro-dosing can be significantly greater than depletion by plants that do not receive fertilizer. In other words, micro-dosing might not be a sustainable technology because it might lead to even more soil degradation than zero fertilizer application. The current results showed that millet response to fertilizer micro-dosing can be improved through deep placement of fertilizer, leading to an increase in root development which results in increased millet yield. In addition, the current work demonstrated that there is a need to identify the limiting factors for fertilizer application in Sahelian soils and to study the long term effects of fertilizer microdosing on soil fertility.

This study was funded by the Systems and Crops Diversification Program, ICRISAT-Niamey. The authors are grateful to Moustapha Amadou, Technician of Systems and Crops Diversification Program for helping in data collection.

\section{REFERENCES}

Aune, J. B. \& BAtiono, A. (2008). Agricultural intensification in the Sahel - the ladder approach. Agricultural Systems 98, 119-125.

Bagayoko, M., Alvey, S., Neumann, G. \& Buerkert, A. (2000a). Root-induced increases in soil pH and nutrient availability to field-grown cereals and legumes on acid sandy soils of Sudano-Sahelian West Africa. Plant and Soil 225, $117-127$.
Bagayoko, M., George, E., Römheld, V. \& Buerkert, A. $(2000 b)$. Effects of mycorrhizae and phosphorus on growth and nutrient uptake of millet, cowpea and sorghum on a west African soil. The Journal of Agricultural Science, Cambridge 135, 399-407.

Bagayoko, M., Maman, N., Palé, S., Sirifi, S., Taonda, S. J. B., Traore, S. \& Mason, S. C. (2011). Microdose and N and P fertilizer application rates for pearl millet in West Africa. African Journal of Agricultural Research 6, 1141-1150.

Bationo, A. \& Mokwunye, A. U. (1991). Alleviating soil fertility constraints to increased crop production in West Africa: the experience in the Sahel. In Alleviating Soil Fertility Constraints to Increased Crop Production in West Africa (Ed. A. U. Mokwunye), pp. 195-215. Developments in Plant and Soils Sciences vol. 47. Dordrecht, the Netherlands: Kluwer Academic Publishers.

BAtIONO, A. \& Waswa, B. (2011). New challenges and opportunities for integrated soil fertility management in Africa. In Innovations as Key to the Green Revolution in Africa (Eds A. Bationo, B. Waswa, J. M. Okeyo, F. Maina \& J. M. Kihara), pp. 3-17. Dordrecht, The Netherlands: Springer.

Bationo, A., Christianson, C. B. \& Klalj, M. C. (1993). The effect of crop residue and fertilizer use on pearl millet yields in Niger. Fertilizer Research 34, 251-258.

Bationo, A., Lompo, F. \& Koala, S. (1998). Research on nutrient flows and balances in West Africa: state-of-the-art. Agriculture, Ecosystems and Environment 71, 19-35.

Buerkert, A. \& Hiernaux, P. (1998). Nutrients in the West African Sudano-Sahelian zone: Losses, transfers and role of external inputs. Zeitschrift für Pflanzenernährung und Bodenkunde 161, 365-383.

Buerkert, A., Bationo, A. \& Piepho, H.-P. (2001). Efficient phosphorus application strategies for increased crop production in sub-Saharan West Africa. Field Crops Research 72, 1-15.

Fatondjl, D., Pasternak, D. \& Woltering, L. (2008). Watermelon production on stored rainwater in Sahelian sandy soils. African Journal of Plant Science 2, 151-160.

Hafner, H., George, E., Bationo, A. \& Marschner, H. (1993). Effect of crop residues on root growth and phosphorus acquisition of pearl millet in an acid sandy soil in Niger. Plant and Soil 150, 117-127.

Houba, V. J. G., Van der Lee, J. J. \& Novozamsky, I. (1995). Soil Analysis Procedures; Other Procedures (Soil and Plant Analysis, part 5B). Wageningen, The Netherlands: Department of Soil Science \& Plant Nutrition, Wageningen Agricultural University.

KlalJ, M. C. \& VaChaUd, G. (1992). Seasonal water balance of a sandy soil in Niger cropped with pearl millet, based on profile moisture measurements. Agricultural Water Management 21, 313-330.

Lawes Agricultural Trust (2007). Genstat Version 9. Rothamsted, UK: Lawes Agricultural Trust (Rothamsted Experimental Station).

Marenya, P. P. \& Barrett, C. B. (2009). State-conditional fertilizer yield response on western Kenyan farms. American Journal of Agricultural Economics 91, 991-1006.

Muehlig-Versen, B., Buerkert, A., Bationo, A. \& Roeheld, V. (2003). Phosphorus placement on acid arenosols of the 
west African Sahel. Experimental Agriculture 307-325.

Newman, E. I. (1966). A method of estimating the total length of root in a sample. Journal of Applied Ecology 3, 139-145.

Sivakumar, M. V. K. \& SalaAm, S. A. (1999). Effect of year and fertilizer on water-use efficiency of pearl millet (Pennisetum glaucum) in Niger. The Journal of Agricultural Science, Cambridge 132, 139-148.

Soil Survey Staff (1999). Soil Taxonomy: A Basic System of Soil Classification for Making and Interpreting Soil Surveys, 2nd edn, U.S. Department of Agriculture Handbook 436. Washington, DC: USDA Natural Resources Conservation Service.

Stoorvogel, J. J. \& Smaling, E. M. A. (1990). Assessment of Soil Nutrient Depletion in Sub-Saharan Africa: 19832000. Report no. 28. Wageningen, The Netherlands: Winand Staring Centre.

Tabo, R., Bationo, A., Gerard, B., Ndjeunga, J., Marchal, D., Amadou, B., Annou, M. G., Sogodogo, D., Taonda, J.-B. S., Hassane, O., Diallo, M. K. \& Koala, S. (2007). Improving cereal productivity and farmers' income using a strategic application of fertilizers in West Africa. In Advances in Integrated Soil Fertility Management in Sub-Saharan Africa: Challenges and Opportunities (Eds A. Bationo, B. Waswa, J. Kihara, \& J. Kimetu), pp. 201-208. Dordrecht, The Netherlands: Springer.
Tennant, D. (1975). A test of a modified line intersect method of estimating root length. The Journal of Ecology 63, 995-1001.

Twomlow, S., Rohrbach, D., Dimes, J., Rusike, J., Mupangwa, W., Ncube, B., Hove, L., Moyo, M., Mashingaidze, N. \& Mahposa, P. (2011). Micro-dosing as a pathway to Africa's Green Revolution: evidence from broad-scale on-farm trials. In Innovations as Key to the Green Revolution in Africa: Exploring the Scientific Facts (Eds A. Bationo, B. Waswa, J. M. Okeyo, F. Maina \& J.M. Kihara), pp. 1101-1113. Dordrecht, The Netherlands: Springer.

Von LieBIG, J. (1940). Chemistry in its Application to Agriculture and Physiology. London: Taylor and Walton.

WalkLeY, A. \& Black, I. A. (1934). An examination of the Degtjareff method for determining soil organic matter, and a proposed modification of the chromic acid titration method. Soil Science 37, 29-38.

West, L. T., Wilding, L. P., Landeck, J. K. \& Calhoun, F. G. (1984). Soil Survey of the ICRISAT Sahelian Center, Niger, West Africa. Soil and Crop Sciences Department/ TROPSOILS. College Station, TX: Texas A\&M University.

Zingore, S., Delve, R. J., Nyamangara, J. \& Giller, K. E. (2008). Multiple benefits of manure: the key to maintenance of soil fertility and restoration of depleted sandy soils on African smallholder farms. Nutrient Cycling in Agroecosystems 80, 267-282. 